OECD Environment Working Papers No. 88

\section{Competitiveness Impacts \\ of the German Electricity}

Tax

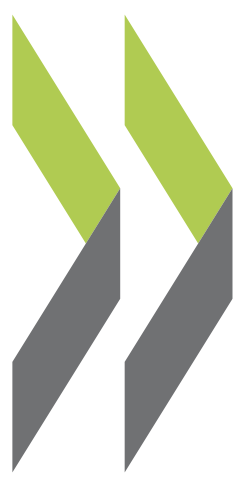

Florens Flues,

\section{Benjamin Johannes Lutz}


Organisation de Coopération et de Développement Économiques

Organisation for Economic Co-operation and Development

12-May-2015

ENVIRONMENT DIRECTORATE

English - Or. English

\section{COMPETITIVENESS IMPACTS OF THE GERMAN ELECTRICITY TAX - ENVIRONMENT WORKING PAPER No. 88}

by Florens Flues (1) and Benjamin Johannes Lutz (2)

OECD Working Papers should not be reported as representing the official views of the OECD or of its member countries. The opinions expressed and arguments employed are those of the author(s).

(1) OECD Environment Directorate and OECD Centre for Tax Policy and Administration

(2) Centre for European Economic Research (ZEW)

Authorised for publication by Simon Upton, Director, OECD Environment Directorate.

JEL classification: D22, H21, H23, Q41, Q48

Keywords: environmental taxation, competitiveness impacts, tax expenditures

OECD Environment Working Papers are available at www.oecd.org/env/workingpapers.htm

JT03376034

Complete document available on OLIS in its original format

This document and any map included herein are without prejudice to the status of or sovereignty over any territory, to the delimitation of international frontiers and boundaries and to the name of any territory, city or area. 


\section{OECD ENVIRONMENT WORKING PAPERS}

OECD Working Papers should not be reported as representing the official views of the OECD or of its member countries. The opinions expressed and arguments employed are those of the author(s).

OECD Working Papers describe preliminary results or research in progress by the author(s) and are published to stimulate discussion on a broad range of issues on which the OECD works.

This series is designed to make available to a wider readership selected studies on environmental issues prepared for use within the OECD. Authorship is usually collective, but principal author(s) are named. The papers are generally available only in their original language -English or French- with a summary in the other language.

Comments on Working Papers are welcomed, and may be sent to:

Environment Directorate

OECD, 2 rue André-Pascal, 75775 Paris Cedex 16, France

or by e-mail: env.contact@oecd.org

OECD Environment Working Papers are published on www.oecd.org/env/workingpapers.htm

This document and any map included herein are without prejudice to the status of or sovereignty over any territory, to the delimitation of international frontiers and boundaries and to the name of any territory, city or area.

The statistical data for Israel are supplied by and under the responsibility of the relevant Israeli authorities. The use of such data by the OECD is without prejudice to the status of the Golan Heights, East Jerusalem and Israeli settlements in the West Bank under the terms of international law.

\section{(C) OECD (2015)}

You can copy, download or print OECD content for your own use, and you can include excerpts from OECD publications, databases and multimedia products in your own documents, presentations, blogs, websites and teaching materials, provided that suitable acknowledgment of OECD as source and copyright owner is given.

All requests for commercial use and translation rights should be submitted to rights@ oecd.org. 


\section{TABLE OF CONTENTS}

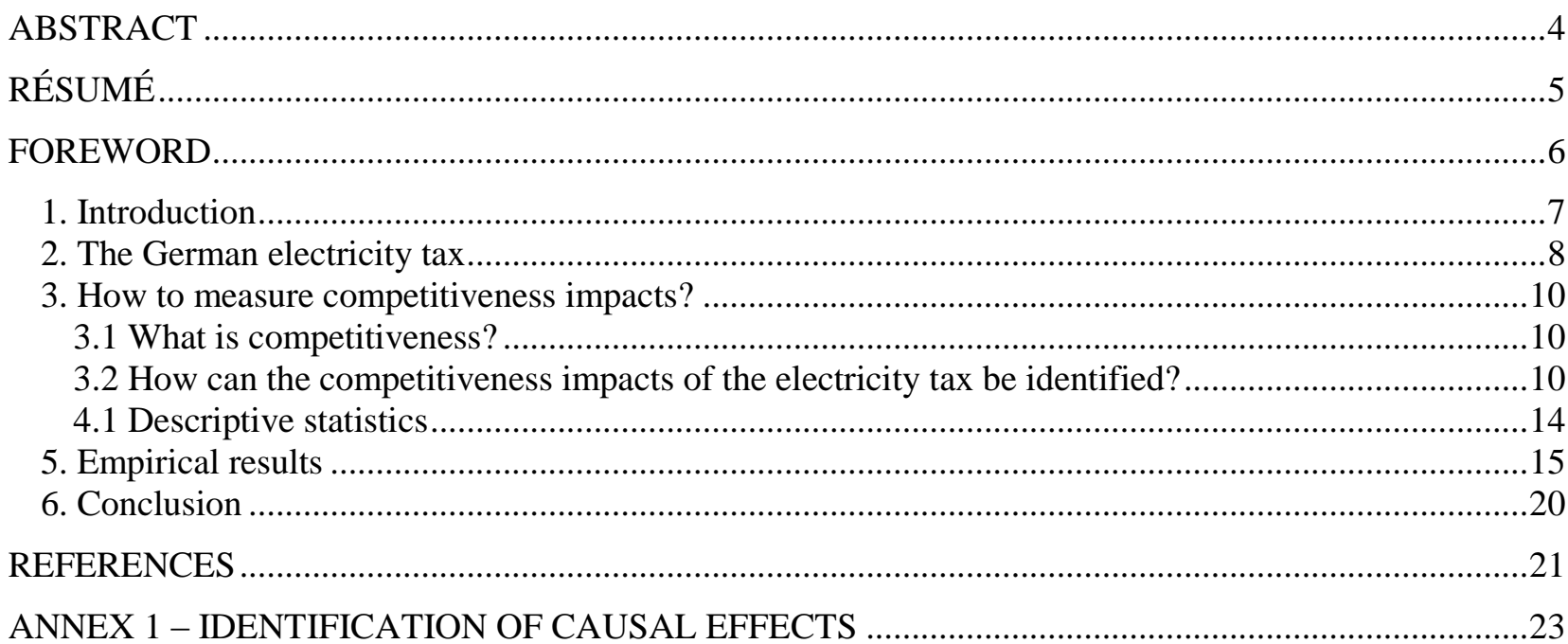




\begin{abstract}
Proposals to increase environmentally related taxes are often challenged on competitiveness grounds. The concern is that value creation in certain sectors might decline domestically if a country introduces environmentally related taxes unilaterally. Furthermore, environmental goals might not be reached if pollution shifts abroad. A competing view argues that properly implemented environmentally related taxes foster innovation, thereby boosting productivity and competitiveness. Empirical research is needed to gain insight into the strength of these various effects. This paper provides evidence on the short-term competitiveness impacts of the German electricity tax introduced unilaterally in 1999.

Germany's manufacturing sector uses significant amounts of electricity, and to counteract potential negative effects on competitiveness, relief was provided: firms using more electricity than specified thresholds benefitted from reduced electricity tax rates. The tax reduction amounted up to EUR 14.6 per megawatt hour, about $80 \%$ of the full tax rate. When measured as an effective rate on the carbon content in the average unit of electricity, the electricity tax translates into EUR 44.4 per tonne of carbon dioxide, indicating the magnitude of the tax.

The econometric analysis - a regression discontinuity design - shows no robust effects in either direction of the reduced electricity tax rates on firms' competitiveness. Firms subject to the full tax rates, but otherwise similar to firms facing reduced rates, did not perform worse in terms of turnover, exports, value added, investment and employment. The analysis questions the relevance of the tax reduction for competitiveness reasons and suggests that it could be gradually removed. The energy use threshold, above which a reduced tax rate applies, could be raised over time and competitiveness impacts monitored.
\end{abstract}

Keywords: environmental taxation, competitiveness impacts, tax expenditures

JEL classification: D22, H21, H23, Q41, Q48 
ENV/WKP(2015)9

\section{RÉSUMÉ}

Les propositions visant à augmenter les taxes liées à l'environnement sont souvent contestées en invoquant des motifs liés à la compétitivité. Le souci à cet égard tient au risque de voir la création de valeur diminuer dans certains secteurs d'un pays si celui-ci adopte unilatéralement ce type de taxes sur son territoire. En outre, il se peut que les objectifs d'environnement ne soient pas atteints si la pollution se déplace au-delà de ses frontières. A contrario, on peut considérer que des taxes liées à l'environnement mises en œuvre de façon appropriée stimulent l'innovation et, de ce fait, favorisent la productivité et la compétitivité. Des études empiriques sont nécessaires pour mieux appréhender l'importance de ces divers effets. Ce rapport livre des éléments d'information au sujet des effets à court terme sur la compétitivité de la modification d'une disposition donnée.

L'Allemagne a adopté unilatéralement une taxe sur l'électricité en 1999. Comme le secteur manufacturier allemand consomme beaucoup d'électricité, un allégement fiscal était prévu pour contrecarrer les effets préjudiciables que cette taxe pouvait avoir sur la compétitivité : les entreprises manufacturières dont la consommation d'électricité serait supérieure à certains seuils bénéficieraient d'une taxe à taux réduit. Cet allégement pouvait atteindre 14.6 EUR par mégawattheure, environ $80 \%$ du taux plein. À l'aune du contenu carbone d'une unité moyenne d'électricité, le taux effectif d'imposition est égal à 44.4 EUR par tonne de dioxyde de carbone, c'est dire l'importance de la taxe.

L'analyse économétrique - selon la méthode de discontinuité de la régression - montre que les taux réduits de la taxe sur l'électricité n'ont d'effets significatifs ni positifs ni négatifs sur la compétitivité des entreprises. Les entreprises ne bénéficiant d'aucun allégement, mais présentant par ailleurs des caractéristiques semblables à celles des entreprises qui y avaient droit, n'ont pas affiché de performances moins bonnes qu'elles en termes de chiffre d'affaires, d'exportations, de valeur ajoutée, d'investissement ou d'emploi. L'analyse met en doute la nécessité de la réduction fiscale pour préserver la compétitivité et suggère de la supprimer progressivement. Le seuil de consommation d'énergie au-delà duquel s'applique le taux réduit de la taxe pourrait être relevé par paliers, en assurant un suivi des effets sur la compétitivité.

Mots-clés : taxes environnementales, effets sur la compétitivité, dépenses fiscale

Classification JEL : D22, H21, H23, Q41, Q48 


\section{FOREWORD $^{1}$}

This case study was authored by Florens Flues (OECD Environment Directorate and OECD Centre for Tax Policy and Administration) and Benjamin Johannes Lutz (Centre for European Economic Research (ZEW).

Data and analytical results cited in this paper often draw on a more comprehensive analysis of the German electricity tax targeted towards an academic audience, see Flues and Lutz (2015).

1. The authors would like to thank Nils Axel Braathen, Andreas Gerster, Jonathan Gayotte, Beat Hintermann, Koichiro Ito, Tomasz Kozluk, Stefan Lamp, Andreas Löschel, Ralf Martin, Nico Pestel, Kathrin Sommerfeld, Kurt van Dender, Katherine von Graevenitz, Stefan Vögele and Ulrich Wagner for helpful suggestions and comments. The work also benefitted from discussions with participants of the ASSA Meeting 2015, the $6^{\text {th }}$ AWEEE 2014, the $37^{\text {th }}$ IAEE International Conference 2014, the $19^{\text {th }}$ SMYE 2014 and internal meetings and seminars at the OECD and the ZEW. Jennifer Humbert and Violet Sochay are thanked for editorial assistance. 
ENV/WKP(2015)9

\section{Introduction}

Taxes are a key tool to address environmental goals. However, proposals to introduce or increase environmentally related taxes are often challenged on competitiveness grounds. In particular, it is often argued that domestic production may decline if a country introduces environmentally related taxes unilaterally. In addition, environmental goals might not be reached if pollution just shifts abroad. A competing view argues that properly implemented environmentally related taxes may foster innovation and thereby enhance productivity. These divergent views are mainly grounded in different underlying assessments of the amount and severity of prevailing market failures and of the endogenous nature of technological change.

This paper contributes to the empirical understanding of the competitiveness impacts of environmentally related taxes by analysing the effects of the German electricity tax. The tax was introduced in 1999 and is levied on electricity-use. Since 2003 the full tax rate has been EUR 20.5 per MWh. When measured as an effective rate on the carbon content in the average unit of electricity, this translates to EUR 44.4 per tonne of carbon dioxide $\left(\mathrm{CO}_{2}\right)$, illustrating the significance of the tax. Germany's manufacturing sector uses sizeable amounts of electricity, and to counteract potential negative effects on competitiveness, firms in the manufacturing sector that use more electricity than specified thresholds benefit from reduced electricity tax rates. The tax rate reduction amounted to as much as EUR 14.6 per MWh in 2002. Taking advantage of the rate structure, and utilising data from 1995-2006, the paper applies a regression discontinuity analysis to examine the effect of the reduced electricity tax on various competitiveness-related variables.

The econometric analysis finds that the electricity tax rate reduction has no robust positive or negative effects on firms' competiveness. It is likely that firms base decisions that affect competitiveness-related variables (turnover, investment etc.) on ex ante expectations of the marginal tax rate they will face. If these decisions had led to different outcomes for these variables, then it would reasonably follow that the tax reduction had an impact on competitiveness. However, this study finds that similar firms that did not receive a tax reduction did not perform any differently than those that benefited from the tax reduction. Since no effect on competitiveness is observed, the analysis questions the need for the tax reduction for competitiveness reasons. Furthermore, removing the tax reduction would raise additional revenues that could, for example, be used to reduce distortionary taxes on labour income.

The findings of this paper are consistent with the few available ex post evaluations of the competitiveness impacts of environmentally related taxes (cf. Braathen, 2012). The best example may be Martin, de Preux and Wagner's (2012) study on the impact of climate change agreements in the UK. These agreements allow energy-intensive firms an $80 \%$ reduction on the Climate Change Levy. Their results show that firms which did not participate in the climate change agreements and were subject to the full tax rate did not have lower output or employment than largely similar firms that participated in the agreements. In other words, applying the full tax rate did not have detrimental effects on firms' output or employment. In another study, Rivers and Schaufele (2013) do not find any effects of the carbon tax in British Columbia on agricultural gross or net export. While these studies do not find any significant negative effects of environmental taxes on firms' competitiveness in the UK and British Columbia, evidence from other countries can improve the understanding of competitiveness effects of environmental taxes. Arlinghaus (2015) provides a more comprehensive review of the few ex post evaluations of competitiveness impacts of environmentally related taxes, also reviewing emission trading schemes. Kozluk and Zipperer (2013) review the relationship between the stringency of environmental policies and productivity growth more broadly. The present paper contributes to this literature with an ex post evaluation of the German electricity tax. 
The paper is structured as follows. Section 2 provides background on the German electricity tax. Section 3 explains which competitiveness effects are evaluated and how they are identified using regression discontinuity analysis. Section 4 presents the dataset and provides descriptive statistics. Section 5 discusses the results of the regression discontinuity analysis. Section 6 concludes.

\section{The German electricity tax}

The German electricity tax was introduced in 1999 with the goal of improving energy efficiency and allowing a lowering of labour costs. The new electricity tax increased the price on electricity, thus providing incentives to reduce electricity-use. The revenues are utilised to lower social security contributions, and thereby overall labour costs.

The electricity tax is levied on electricity-use as an ad-quantum excise duty. The current full rate is EUR 20.5 per MWh. Compared to the average yearly wholesale price for electricity, which ranged from about EUR 30 to EUR 65 per MWh between 2003 and 2010 (EEX, 2014), the tax rate is significant in size. It implies an effective tax on the carbon content in the average unit of electricity of EUR 44.4 per tonne of carbon dioxide $\left(\mathrm{CO}_{2}\right)$. Although this calculation boldly assumes that the generation mix of electricity would not change, if the tax was levied on $\mathrm{CO}_{2}$ instead of on electricity, it gives an alternative indication of the significance of the electricity tax.

The government, which was concerned that the electricity tax could harm the competitiveness of the most energy-intensive firms, took at least two measures. First, it introduced the electricity tax in several steps until the full rate was reached in 2003, giving firms time to adjust to higher electricity prices. Second, it provided relief to manufacturing sectors through reduced tax rates.

The reduced tax rates apply from certain thresholds of electricity-use onwards. While every electricity-user has to pay the same tax rate for any use below the threshold, firms in the manufacturing sector are eligible for a reduced marginal tax rate for any use above the threshold. Table 1 provides an overview of the development of the full and reduced marginal tax rates, as well as the electricity-use thresholds for reduced marginal tax rates.

The electricity tax is an indirect tax that is levied on the supply of electricity. Consequently, every firm pays the full tax rate when it settles the invoice of the electricity provider. The tax reduction scheme is implemented through reimbursement. Firms whose electricity-use exceeds the threshold may request reimbursement from the local tax and customs agency.

Table 1. Phasing-in electricity tax rate

\begin{tabular}{l|rrrrrr}
\hline $\begin{array}{c}\text { Electricity-use threshold } \\
\text { (per year) }\end{array}$ & \multicolumn{5}{|c}{ Marginal electricity tax rate in EUR per MWh } \\
& Until 1999 & 1999 & 2000 & 2001 & 2002 & $2003-2010$ \\
\hline Below 25 MWh & 0 & 10 & 12.5 & 15 & 17.9 & 20.5 \\
Above 25 MWh & 0 & 10 & 12.5 & 15 & 17.9 & 12.3 \\
Above 28.6 MWh & 0 & 10 & 12.5 & 15 & 3.6 & 12.3 \\
Above 33 MWh & 0 & 10 & 12.5 & 3 & 3.6 & 12.3 \\
Above 40 MWh & 0 & 10 & 2.5 & 3 & 3.6 & 12.3 \\
Above 50 MWh & 0 & 2 & 2.5 & 3 & 3.6 & 12.3 \\
\hline
\end{tabular}

A threshold of $50 \mathrm{MWh}$ or lower for a reduced marginal electricity tax rate seems low, but many firms in the manufacturing sector use about that much electricity. Figure 1 shows two histograms of the distribution of firms in the manufacturing sector ordered across their electricity-use. A "bin" corresponds 
to a $200 \mathrm{MWh}$ range in the left panel and a $20 \mathrm{MWh}$ range in the right panel. The left panel shows that there are very few firms with electricity-use above $2000 \mathrm{MWh}$ per year while there are many more firms consuming less than $2000 \mathrm{MWh}$. The lowest bin in terms of electricity-use, which corresponds to an electricity-use of 0 to $200 \mathrm{MWh}$, contains more than 15000 out of about 40000 firms in the manufacturing sector. The right panel zooms in on the range of firms using less than $1000 \mathrm{MWh}$ of electricity. It clearly shows that there are many more firms in the bins close to thresholds for a reduced electricity tax rate, i.e. around 25 to $50 \mathrm{MWh}$, than in bins with higher electricity-use. These firms are directly affected by either having to pay the reduced or the full marginal electricity tax rate.

Figure 1. Distribution of firms across electricity-use
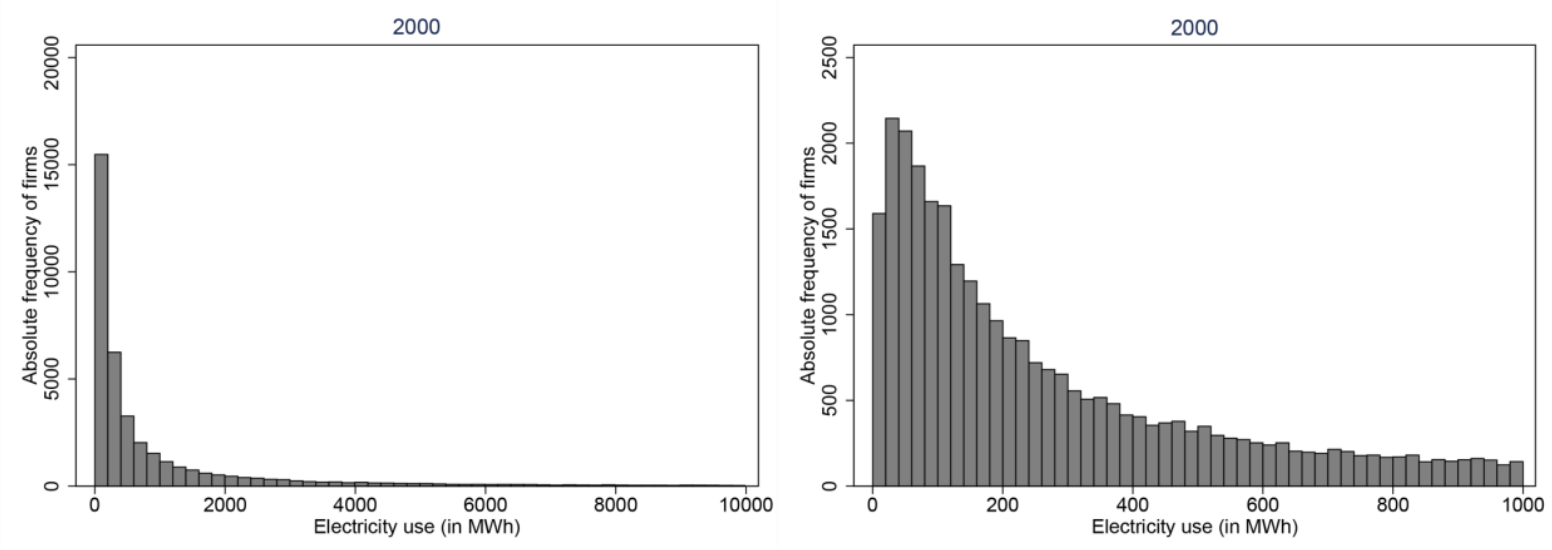

Source: Flues and Lutz (2015). "The effect of electricity taxation on the German manufacturing industry", Discussion Paper No. 15013, ZEW, Mannheim.

The reduced marginal tax rate for any electricity-use above the threshold in a given year generates random variation in firms' marginal electricity tax rates. Whether firms face the full or reduced marginal tax rate is essentially a question of chance due to arbitrarily set thresholds. This random variation is later used to identify the effects of the reduced marginal tax rates on firms' economic performance. In Section 3.2, the corresponding regression discontinuity design is explained in more detail.

There is another type of electricity tax reduction in Germany, the so-called Spitzenausgleich. The revenues from the electricity tax are used to lower social security contributions on labour, as indicated before. While firms benefit from reduced social security contributions it is possible that they end up with overall higher costs due the new electricity tax. The Spitzenausgleich reimburses a certain percentage of the potential additional burden from the new electricity tax net of the savings on social security contributions. The reimbursement rule and the reduction in social security contributions have changed several times.

The Spitzenausgleich applies only for electricity-use above the same thresholds from which the reduced marginal electricity tax rate is granted. Thereby it may add to the potential effects of the reduced marginal tax rates. The effects of the reduced tax rate very likely dominate around the thresholds given non-negligible administrative procedures for receiving the Spitzenausgleich. This paper refers to the effects of the reduced tax rate, bearing in mind that some of effects may have been reinforced by the Spitzenausgleich.

In August 2006, exemptions to the electricity tax were granted for firms in the manufacturing sectors for the electricity consumed in various production processes. In particular, electricity used for electrolysis, production of glass, ceramics, fertilizers, metal production and processing, as well as chemical reduction 
processes was exempted from the electricity tax. These tax exemptions apply for all electricity-use and thus not only from above certain threshold onwards. There is no information on how much electricity is used for these processes. From 2006 onwards, it cannot be identified any more which firms could benefit, and to what extent, from the reduced marginal electricity tax rate. The effects of the reduced marginal electricity tax rate are therefore analysed only until 2005.

As mentioned, the revenues from the electricity tax are used to lower social security contributions. Given that the reduction of social security contributions applies to all firms uniformly, it is not possible to measure the effect of the reduction in social security contributions, nor can the overall effect of the reform package be assessed (i.e. the introduction of a new electricity tax combined with the use of its revenues to lower social security contributions). The present analysis limits itself to assessing how different marginal electricity tax rates affected firms' competitiveness.

\section{How to measure competitiveness impacts?}

This section discusses what is meant by competitiveness and how competitiveness impacts of the electricity tax can be identified.

\subsection{What is competitiveness?}

Competitiveness is a broadly used term referring to the relative performance of firms, sectors, and countries (cf. Smith, 2003). The focus of this study is on the competiveness impact of the German electricity tax at the firm level. At the firm level, competitiveness refers to the ability to sell goods and services and stay in the market, according to Adams (1997). In order to measure competitiveness at the firm level, indicators that express the relative performance of firms are hence needed.

Four indicators that are widely regarded as meaningful performance measures of firms are used to evaluate the competitiveness impacts of the German electricity tax. First, turnover, which measures the income that firms receive from the sale of goods and services. It indicates the current competitive position of one firm to another. Second, investment which estimate to what extent firms aim to extend or decrease their market share, and thus their competitive position. Third, value added, i.e. turnover minus purchases outside the firm, which indicate to what extent a firm is in better or worse position than another firm to create valuable products or services. Fourth, exports, which point to what extent a firm is able to compete in foreign markets. Exports are an indicator of particular interest. The tax raised the price of electricity in Germany, while it did not raise the price of electricity abroad. A change in exports due to the electricity tax may thus indicate whether a unilaterally introduced electricity tax alters the competitive position of domestic firms abroad.

Employment is often considered as a measure of a firm's performance. Whether more employment necessarily relates to a better performance of a firm is not obvious. High employment could also be a sign of employing a less productive labour force and not being able to increase its productivity. Despite this drawback, the analysis includes employment effects as they are of interest.

\subsection{How can the competitiveness impacts of the electricity tax be identified?}

The effects of the reduced marginal electricity tax rates can be identified with a regression discontinuity analysis. This analysis exploits random variation in eligibility for reduced tax rates around the thresholds of the tax rate reduction. This section presents briefly the regression discontinuity analysis and discusses the interpretation of the results. Readers interested in technical details are referred to Annex 1. 
The regression discontinuity analysis builds on variations in the marginal tax rate. Firms that use more electricity face a lower marginal tax rate in comparison to firms that use less electricity. In particular, the reduced tax rate applies if a firm's electricity-use in a given year exceeds the known thresholds as shown in Table 1 above. Hence, the thresholds for tax reductions create sharp discontinuities in the marginal tax rates as a function of a firm's individual electricity-use. These discontinuities in the marginal tax rates generate random variation in the marginal tax rates that firms have to pay for energy use, if they cannot precisely manipulate their energy use. A regression discontinuity analysis is then an analysis of the firms' behaviour right and left of the known thresholds.

The central assumption of a regression discontinuity analysis is that firms cannot precisely manipulate their electricity-use (Lee, 2008). This central assumption is likely to hold for at least two reasons. First, complex production processes in the manufacturing industry make precise manipulation of a firm's electricity-use difficult. Second, exogenous factors lead to random variation in electricity-use. For example, market conditions impact a firm's production decisions and thereby its energy use. The empirical validity of the assumption that firms cannot precisely manipulate their electricity-use is examined in Section 5 .

The level of a firm's electricity-use is determined to a high degree by its size and the deployed production technology. Both characteristics develop over time and are based on a series of decisions. Therefore, the level of electricity-use cannot be easily manipulated in the short run. The arbitrarily chosen thresholds lead to a situation where firms that use similar quantities of electricity face different marginal tax rates. Residual variation in a firm's electricity-use driven by exogenous factors might remain, as explained in the paragraph above. This residual materialises in the course of a year and its random character diminishes steadily. Due to the simplicity of the tax scheme, it is assumed that firms are able to make accurate production decisions based on the correct marginal costs associated with electricity-use by frequently updating the underlying information. As a result, firms facing the higher marginal tax rate also have higher marginal electricity costs than firms facing the lower marginal tax rate.

A simple prediction would be that firms with higher marginal electricity costs perform worse in terms of turnover, investment, value added and exports compared to firms with lower marginal electricity costs. A higher marginal cost for electricity-use translates into higher overall costs for producing the same level of output. If there are two types of firms in the market, those with higher marginal costs are expected to produce a lower output than those with lower marginal costs all else equal.

Noting that the study focuses on the short-run effects of the electricity tax, the above predictions do not take into account that firms may adjust their mix of inputs to production over time. Firms could reduce their electricity-use by investing in a more energy-efficient capital stock. Thereby investment would increase. Firms could also replace general investment with energy-efficiency measures without changing total investment. How long it takes firms to adjust their production mix is ultimately an empirical question.

The effects on employment are not obvious. On the one hand, firms that pay the full tax rate face higher costs and may therefore produce less, also employing fewer people. On the other hand, firms may replace some energy-intensive production with more labour-intensive production and thereby increase employment.

Figure 2 presents illustrative graphs using hypothetical data for discussing the possible results from a regression discontinuity analysis. The vertical line at $50 \mathrm{MWh}$ indicates the threshold for the marginal tax reduction. The dots show the average turnover of all firms within equally spaced "bins" to the right and to the left of the threshold for tax reductions. The lines show regressions with a very flexible functional form, which are fitted separately for observations below the threshold and observations above the threshold. There are three possible results. First, the reduced marginal tax rate on electricity could have a positive 
effect on turnover. This result corresponds to the upper panel in Figure 3. Average turnover to the right of the threshold is clearly higher than average turnover to the left the threshold. This is shown both by the binned turnover averages and the regression lines, which show a strong positive discontinuity at the threshold. The differences in the constants of both regression lines correspond to the positive effect of the reduced marginal tax rates. Second, the reduced marginal tax rates could have no effect on turnover. This result is shown in the middle panel of Figure 2. Neither the binned turnover averages nor the regression lines show that there is any difference in turnover from the right to the left of the threshold. Hence the reduced marginal electricity tax rates had no effect on turnover. Third, the reduced marginal tax rates could have a negative effect on turnover. This result is shown in the lower panel of Figure 2. Average turnover to the right of the threshold is clearly lower than average turnover to the left the threshold. This is shown both by the binned turnover averages and the regression lines, which show a strong negative discontinuity at the threshold. Accordingly, the differences in the constants of both regression lines correspond to negative effect of the reduced marginal tax rates on turnover.

As described in Section 2, the tax scheme is implemented through reimbursement, i.e. firms whose electricity-use exceeds the thresholds can request reimbursement from the tax and customs agency. If firms that were assigned to receive the reduced tax, did in fact receive the reduced tax rate is not observed. Accordingly the effect of the reduced tax rates measures in this case how the reduced tax rate assignment affected firms' behaviour, as opposed to a measure of how the reduced tax rate itself affected firm's behaviour (cf. Pearl, 2000). 
Figure 2. Possible results from a regression discontinuity analysis

Positive effect on turnover of reduced marginal electricity tax rate

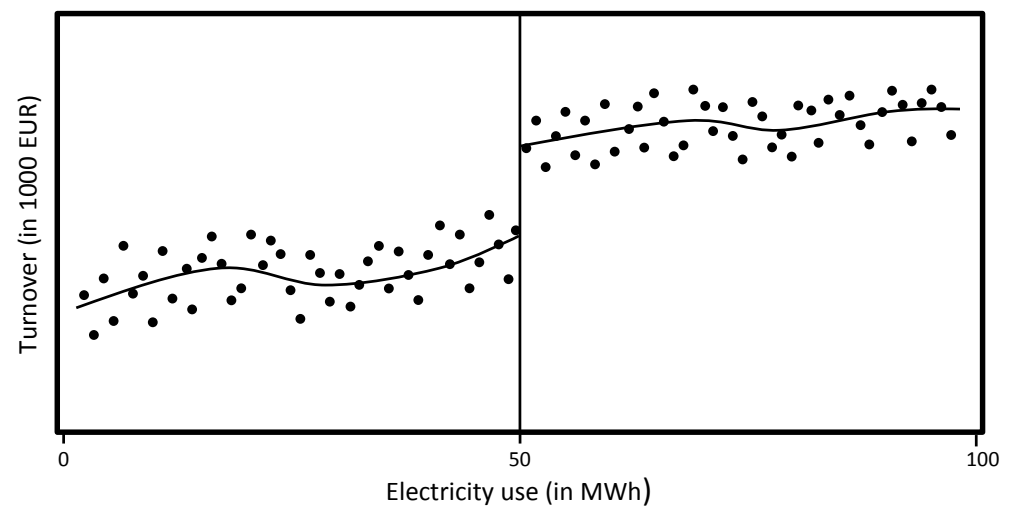

No effect on turnover of reduced marginal electricity tax rate

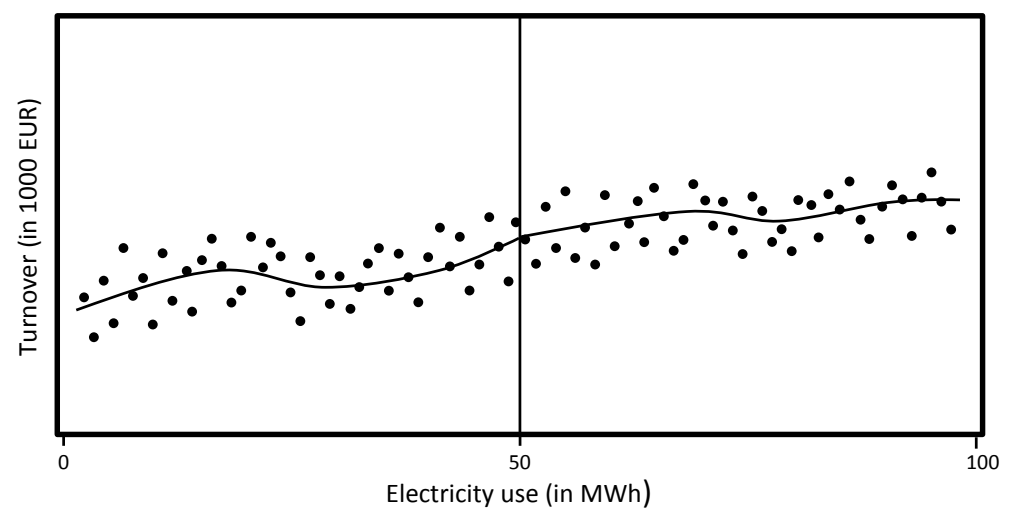

Negative effect on turnover of reduced marginal electricity tax rate

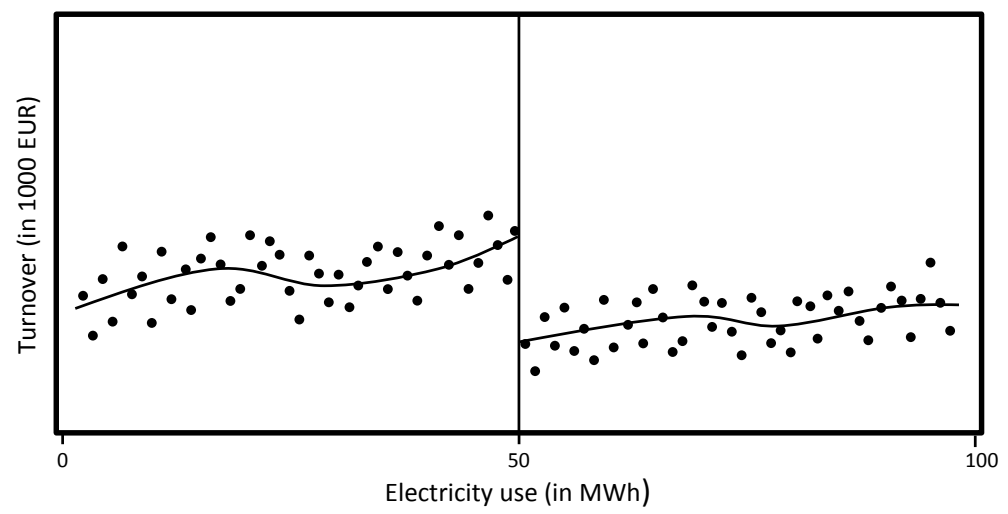


The empirical analysis relies on official micro-data collected by the German Federal Statistical Office and the statistical offices of the German federal states. Data are confidential, but the German statistical offices provide remote data access to researchers for scientific purposes.

The quality of the data is high reflecting in part the mandatory participation in surveys that are conducted by the German statistical offices. Furthermore, many official German government statistics build on this data.

The dataset, called Amtliche Firmendaten für Deutschland (AFiD) (Official Firm Data for Germany), records activities of the industrial sector on plant and firm level. It consists of several modules, which can be combined. In particular, three modules capture activities of the German manufacturing industry.

The core of the dataset is the module AFiD-Panel Industrial Units. This longitudinal census combines annual results from the monthly report on plant operation, the production survey and the survey of investment. The AFiD-Panel Industrial Units is a census of establishments - physical buildings or structures, i.e. plants. It gives detailed information about turnover, employment, costs, investment and firm affiliation.

This database is extended by the module AFiD-Use of Energy. It informs about sale, purchase, generation and distribution of electricity and fuels. The two described modules have the same group of respondents. These are all German plants that operate in the manufacturing industry and employ more than 20 persons.

Last, data from the Cost Structure Survey is added. This survey gives information about the costs of capital, labour and energy use and value added. In contrast to the two previous modules, the Cost Structure Survey collects data only at a firm level. It includes all firms with more than 500 employees. For firms with at least 20 and less than 500 employees, the statistical offices collect a random sample that is stratified by number of employees and industry affiliation. These firms remain four years in the panel and are replaced by a new random sample afterwards.

The modules AFiD-Panel Industrial Units and AFiD-Use of Energy can be aggregated to the firm level and merged with the Cost Structure Survey. The AFiD-Panel Industrial Units contains a variable that identifies the firm affiliation and thus link plants to firms. The resulting dataset comprises longitudinal data on firm level, covering a time span from 1995 to 2005. Thereby the dataset covers pre-reform, reform and post-reform periods. Data is also available for more recent years; yet, as explained in Section 2, additional exemptions from the electricity tax were granted from 2006 onwards, so this study only covers the period up to 2005 .

\subsection{Descriptive statistics}

Table 2 presents descriptive statistics for electricity-use, which determines if firms have to pay the full or the reduced marginal tax rates, as well as the outcome the competitiveness proxy variables: turnover, investment, exports, value added and employment for the years 1995, 2000, and 2005. Turnover, investment, exports and value added are denoted in 1000 EUR. The dataset includes close to 40000 observations per year. The number of observations varies by variable given that information on them stems from different surveys, as explained in the previous section. 
ENV/WKP(2015)9

Table 2. Descriptive Statistics

\begin{tabular}{|c|c|c|c|c|c|c|}
\hline & Mean & $\begin{array}{l}\text { Standard } \\
\text { Deviation }\end{array}$ & $\begin{array}{c}10^{\text {th }} \\
\text { Percentile } \\
\end{array}$ & Median & $\begin{array}{c}90^{\text {th }} \\
\text { Percentile }\end{array}$ & $\begin{array}{c}\text { Number of } \\
\text { Observations }\end{array}$ \\
\hline Electricity-use - 1995 & 1347 & 3474 & 37 & 285 & 3171 & 38470 \\
\hline Electricity-use - 2000 & 1510 & 3969 & 41 & 305 & 3542 & 38784 \\
\hline Electricity-use - 2005 & 1888 & 4938 & 61 & 400 & 4437 & 36158 \\
\hline Turnover - 1995 & 13155 & 23576 & 1423 & 5134 & 31760 & 38579 \\
\hline Turnover - 2000 & 14855 & 25580 & 1520 & 5463 & 36230 & 38873 \\
\hline Turnover - 2005 & 16183 & 30414 & 1483 & 5740 & 39668 & 37329 \\
\hline Investment - 1995 & 594 & 1378 & 0 & 137 & 1490 & 32975 \\
\hline Investment - 2000 & 604 & 1423 & 0 & 136 & 1519 & 36493 \\
\hline Investment - 2005 & 478 & 1193 & 0 & 91 & 1192 & 35111 \\
\hline Exports - 1995 & 2622 & 7803 & 0 & 93 & 6559 & 38579 \\
\hline Exports - 2000 & 3726 & 11063 & 0 & 130 & 9379 & 38873 \\
\hline Exports - 2005 & 4951 & 13909 & 0 & 303 & 12822 & 37329 \\
\hline Value added - 1995 & \multicolumn{6}{|c|}{ Data not available } \\
\hline Value added - 2000 & 8946 & 13821 & 1037 & 3778 & 22868 & 15152 \\
\hline Value added - 2005 & 9503 & 14542 & 1039 & 4089 & 24674 & 13997 \\
\hline Employment - 1995 & 105 & 154 & 23 & 51 & 236 & 38579 \\
\hline Employment - 2000 & 100 & 141 & 23 & 50 & 228 & 38873 \\
\hline Employment - 2005 & 98 & 138 & 23 & 50 & 212 & 37329 \\
\hline
\end{tabular}

Source: Own calculation based on Flues and Lutz (2015).

A high dispersion across firms can be seen when comparing the tenth and the ninetieth percentile of electricity-use and the outcome variables. The percentiles, as well as a comparison of mean and median, show that the distributions of firms over the considered variables are more spread out towards higher values. Therefore, the descriptive statistics reflect the high fraction of small and medium sized firms in the German manufacturing sectors. For the years shown, about $70 \%$ of companies operate only one plant.

When comparing the descriptive statistics over time, there are fewer observations for 2005 than for 2000 and 1995. Two methodological changes contribute to this phenomenon. First, a switch from a monthly to a yearly census in 2003 led to some firms not being surveyed in the subsequent years. Especially some smaller firms may have been temporarily missing from the survey for one or more years. Second, also the classification of economic activity changed in 2003. Those firms that had changed their type of economic activity over time may have verified if their classification in the manufacturing sector was still correct, and reclassified if not.

\section{Empirical results}

The reduced marginal electricity tax rate did not have any robust effects on turnover, investment, exports, value added or employment. This can be seen in Table 3, which summarises the main effects from the regression discontinuity analysis. The left panel of Table 3 summarises the information on the electricity tax. It shows for each year the full tax rate as well as the thresholds from which the reduced marginal tax rate applies and the difference between the full and reduced marginal tax rate. Furthermore, it shows the coverage of the analysis, i.e. the range of electricity-use of all firms analysed. The right panel shows the estimated effects of the regression discontinuity analysis. An empty cell denotes that there is neither a positive nor a negative statistically significant effect. A plus denotes a positive statistically significant effect, a minus a negative statistically significant effect. The 32 statistically non-significant effects clearly outweigh the 3 statistically significant effects. No consistent pattern is seen for the statistically significant effects. In 2001, a positive statistically significant effect of the reduced marginal tax rate on turnover was observed, while in the year 2002, when the difference between the full and the reduced marginal electricity tax rate was highest, a negative statistically significant effect of the reduced marginal tax rate on investment was seen. Overall, the results from the analysis indicate hardly any 
consistent positive or negative effect of the reduced marginal electricity tax on turnover, investment, exports, value added or employment.

Table 3. Summary of regression discontinuity analysis ${ }^{2}$

\begin{tabular}{|c|c|c|c|c|c|c|c|c|c|}
\hline & & & & & \multicolumn{5}{|c|}{ Effect of reduced marginal tax rate on } \\
\hline Year & $\begin{array}{l}\text { Threshold } \\
\text { for } \\
\text { reduced } \\
\text { tax rate in } \\
\text { MWh }\end{array}$ & $\begin{array}{c}\text { Full tax } \\
\text { rate } \\
\text { in } \\
\text { EUR/MWh }\end{array}$ & $\begin{array}{c}\text { Difference } \\
\text { between full } \\
\text { and } \\
\text { reduced } \\
\text { marginal } \\
\text { tax rate in } \\
\text { EUR/MWh }\end{array}$ & $\begin{array}{c}\text { Coverage } \\
\text { firms } \\
\text { consuming } \\
\text { between } x \\
\text { and } y \\
\text { MWh } \\
x-y\end{array}$ & Turnover & Investment & Exports & $\begin{array}{l}\text { Value } \\
\text { added }\end{array}$ & Employment \\
\hline 1999 & 50 & 10 & 8 & $25-75$ & & & & & \\
\hline 2000 & 40 & 12.5 & 10 & $15-65$ & & & & & \\
\hline 2001 & 33 & 15 & 12 & $8-58$ & + & & & & \\
\hline 2002 & 28.6 & 17.9 & 14.6 & $3.6-53.6$ & & - & & & \\
\hline 2003 & 25 & 20.5 & 8.2 & $0-50$ & & & & & \\
\hline 2004 & 25 & 20.5 & 8.2 & $0-50$ & & & & & \\
\hline 2005 & 25 & 20.5 & 8.2 & $0-50$ & & & + & & \\
\hline
\end{tabular}

Notes: empty: no statistically significant effect of reduced tax rate on outcome ( $p$-value $>.05) ;+$ : statistically significant positive effect of reduced tax rate on outcome (sign of regression discontinuity coefficient positive and $p$-value $<=.05$ ); $-:$ statistically significant negative effect on outcome (sign of regression discontinuity coefficient negative and $p$-value $<=.05$ )

Source: Own illustration based on Flues and Lutz (2015).

Figure 3 provides more details on the regression discontinuity analysis. The panels in the first column show the results for five outcome variables: turnover, investment, exports, value added and employment in 2000 , while the panels in the second column show the results for the same variables in 2005. As described in Section 3, the vertical lines at $40 \mathrm{MWh}$ in 2000 and $25 \mathrm{MWh}$ in 2005 indicate the thresholds for tax rate reductions. A positive effect of the reduced tax rate on one of the outcome variables would be indicated by an upward shift to the right of the thresholds of both the binned averages and the regression lines. A negative effect on one of the outcome variables would be indicated by a downward shift to the right of the thresholds of both the binned averages and the regression lines.

For both turnover and investment, no significant discontinuities are observed. The small breaks that are seen for turnover in 2000 and for investment in 2005 are likely due to less precise estimation at the thresholds than further away from them. Individual observations that are substantially higher or lower than neighbouring observations tend to have a bigger impact on the estimated regression lines when they are at an endpoint of the regression line than when they are in the middle of the regression line. Neighbouring observations balance individual high or low observations. In the middle of the regression line such individual high or low observations are balanced by neighbouring observations both to the right and left, while at the endpoints they can only be balanced by observations to one side.

For exports in the year 2005, some discontinuity at the threshold is observed and Table 3 indicates a positive statistically significant effect of the reduced tax rate. This effect is, however, not robust across alternative specifications. The results in Table 3 show the results from regressions with a linear functional form. Such a functional form may generate bias when data is inherently non-linear. Exports are not statistically significant when choosing a quadratic functional form for the regressions (cf. Flues and Lutz, 2015). In addition, exports become statistically insignificant when increasing the size of the intervals for which the regressions are estimated. A larger interval offers more precise estimates as it includes more observations.

For value added and employment, no discontinuities at the thresholds are observed.

2 Details on the estimation procedure are provided in Flues and Lutz (2015). 
Figure 3. Effects of reduced marginal tax rate at discontinuity 2000 2005
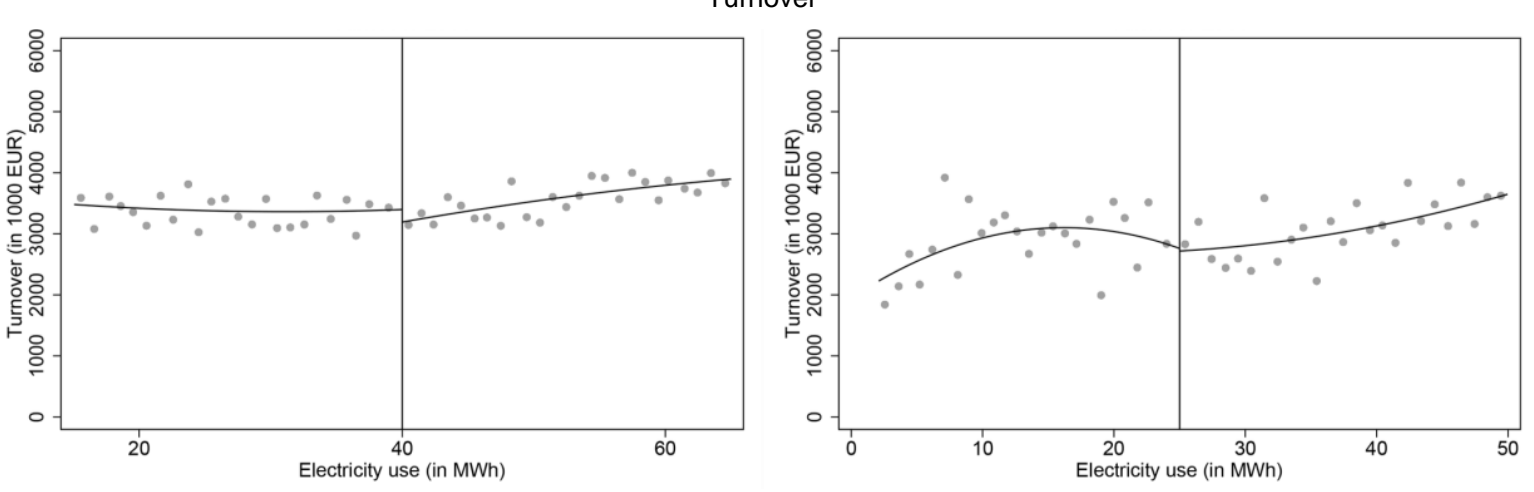

Investment
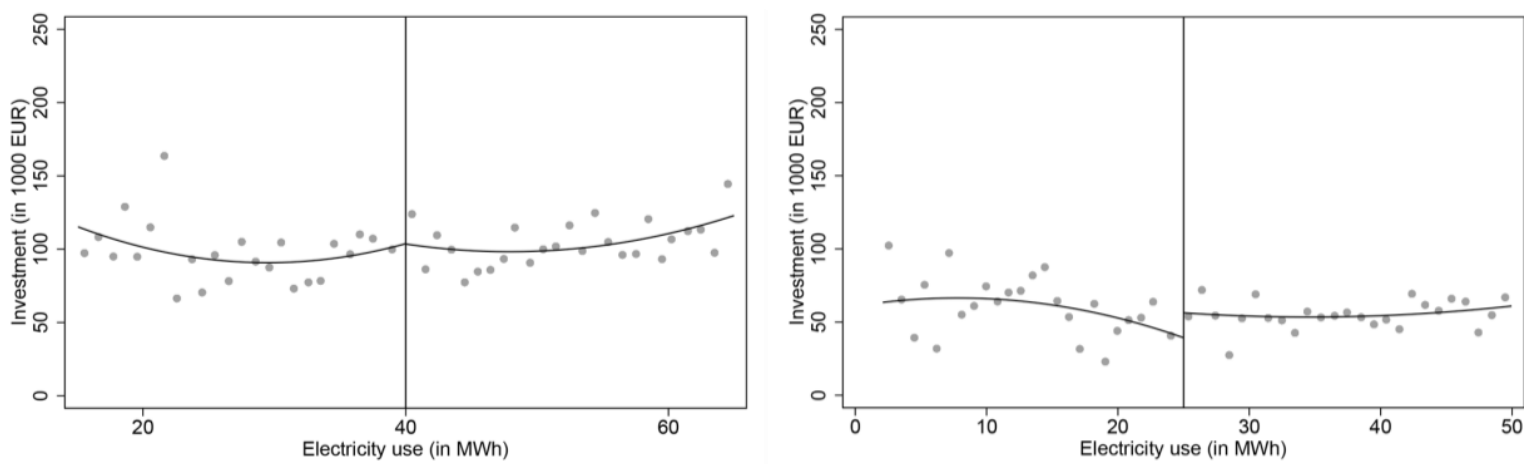

Exports
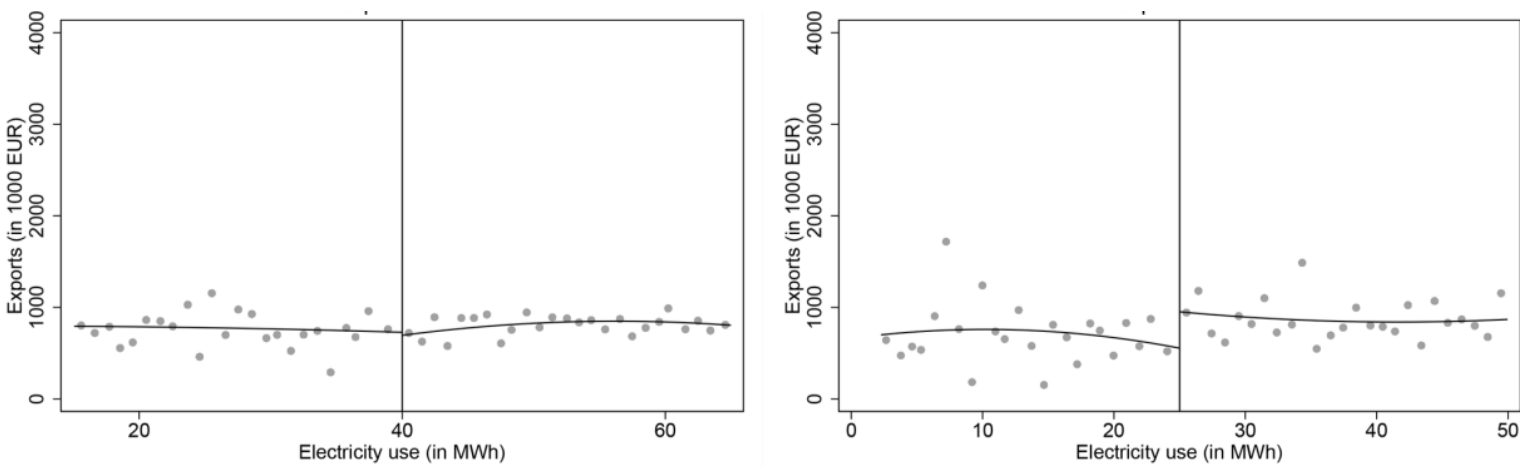

Value added
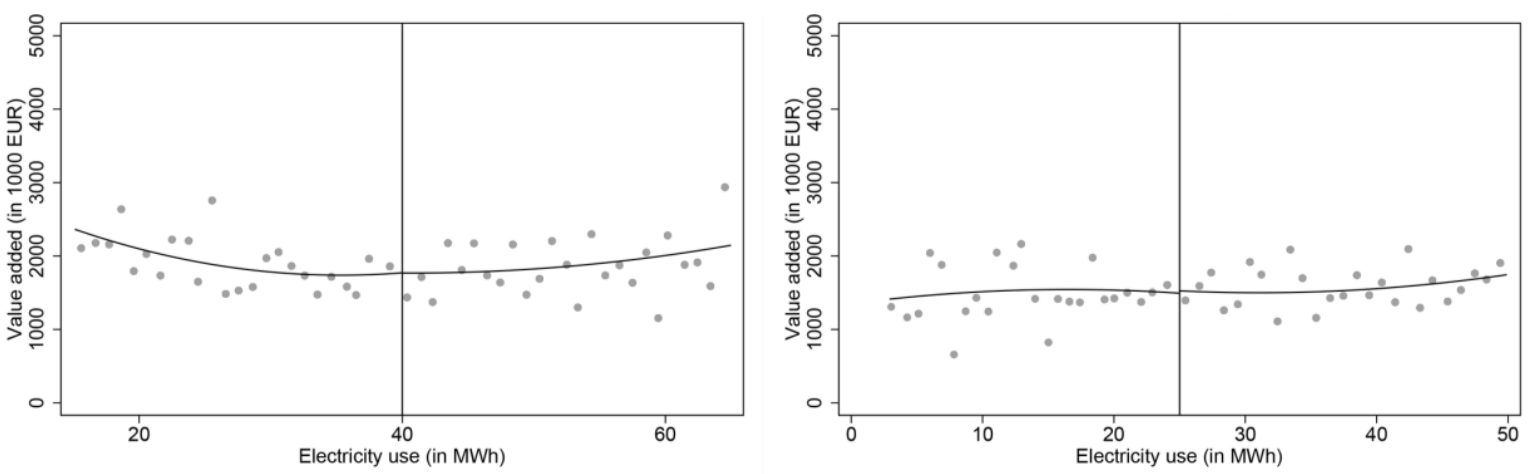


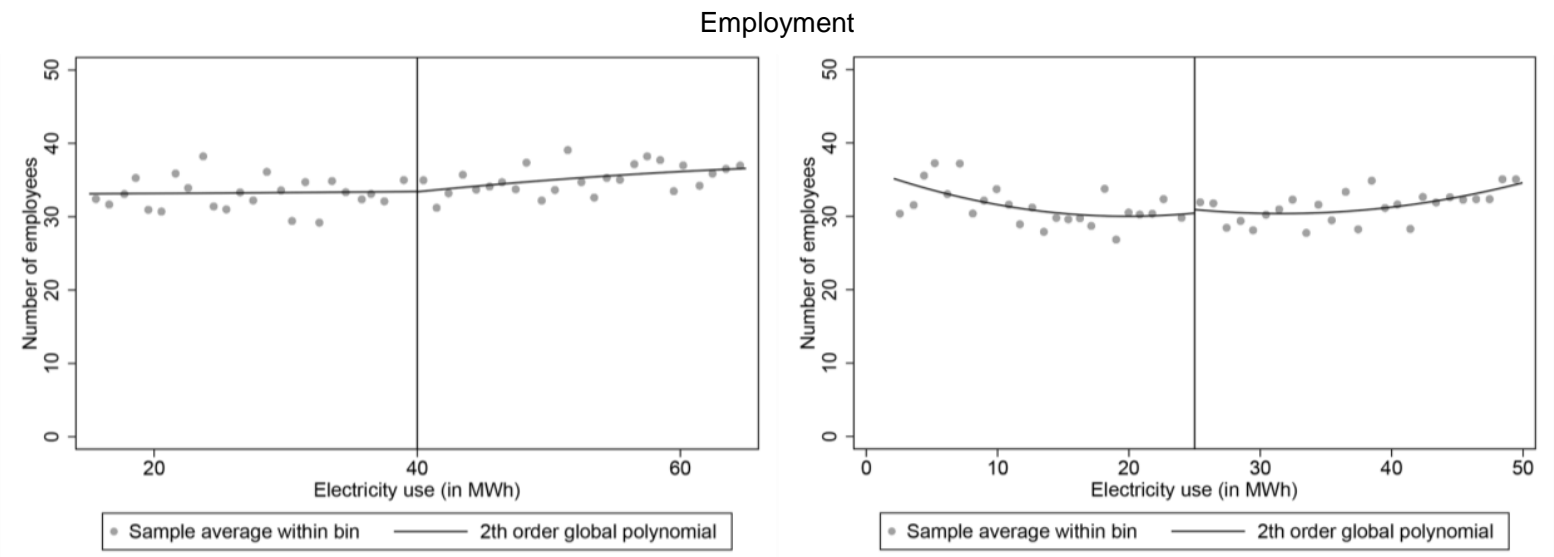

Source: Flues and Lutz (2015), ibid.

Figure 4 investigates whether firms manipulated their electricity-use to qualify for the lower tax rate. There is clearly no evidence for that in 2000. The number of firms within the bin directly above the 40 MWh threshold is only slightly above the number of firms within the bin directly below the threshold. The difference in the number of firms between two bins further away from the threshold is often substantially bigger than the difference between the two bins above and below the threshold. Hence, there is no evidence that firms manipulated their electricity-use to receive the lower tax rate in 2000. For 2005, a small difference is seen between the two bins directly below and directly above the thresholds. However, compared to differences between two bins further away from the thresholds the difference does not look particularly large. Hence, empirically it seems unlikely that firms manipulated their electricity-use in 2005 to receive the lower marginal electricity tax rate.

Figure 4. Distribution of firms around thresholds
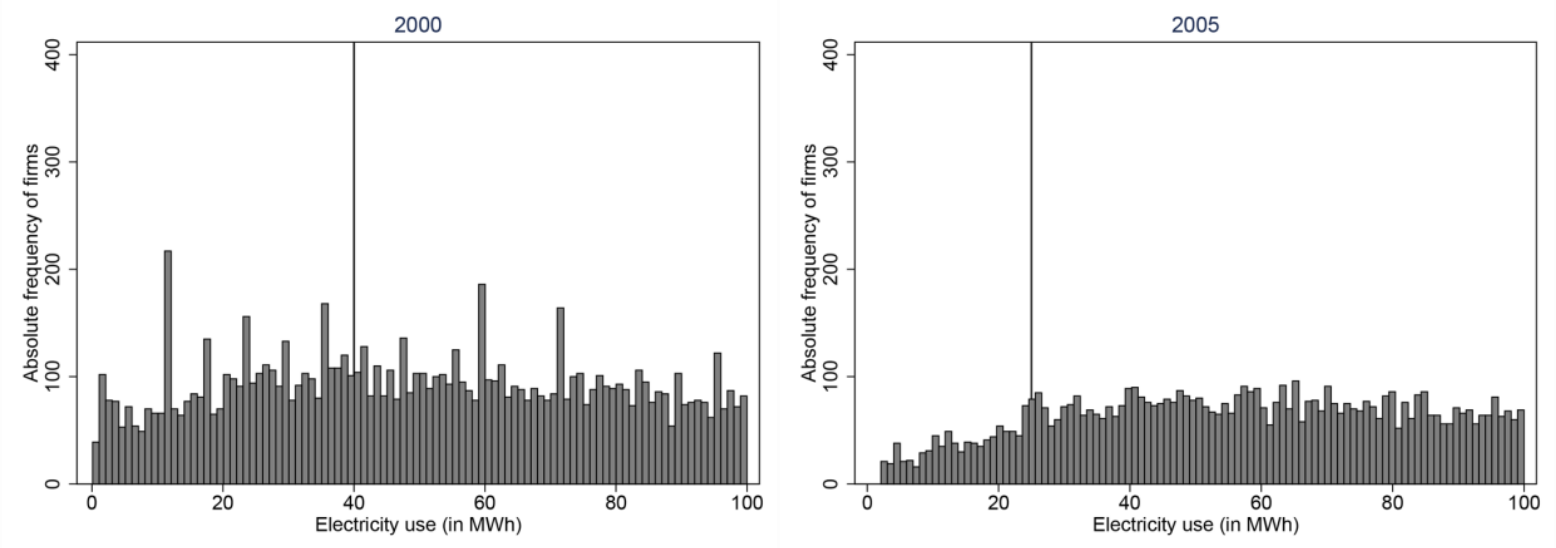

Source: Flues and Lutz (2015), ibid.

Figure 5 shows the regression discontinuity graphs for 1995, prior to the implementation of the electricity tax, as robustness check. There are two possibilities for observing a discontinuity in outcomes variables in 1995. First, there was already some discontinuity in the respective outcome variable for some unknown reasons. This would imply that one should investigate whether the discontinuity has changed and also would lead to some doubts whether firms to the right and to the left of the threshold are really comparable. Second, such a discontinuity could be the result of an oversensitive choice of bins and regression specifications. This would imply that it should be investigated whether the discontinuity holds for other specification choices. 
The hypothetical threshold investigated in Figure 5 is $50 \mathrm{MWh}$, which corresponds to the threshold when the electricity tax was implemented in 1999. The results do not indicate any significant discontinuity, neither in bins nor in the regression lines. Hence, there is no indication for a pre-existing discontinuity or an oversensitive choice of bin and regression specifications.

Figure 5. Turnover, investment, exports, and employment prior to reform
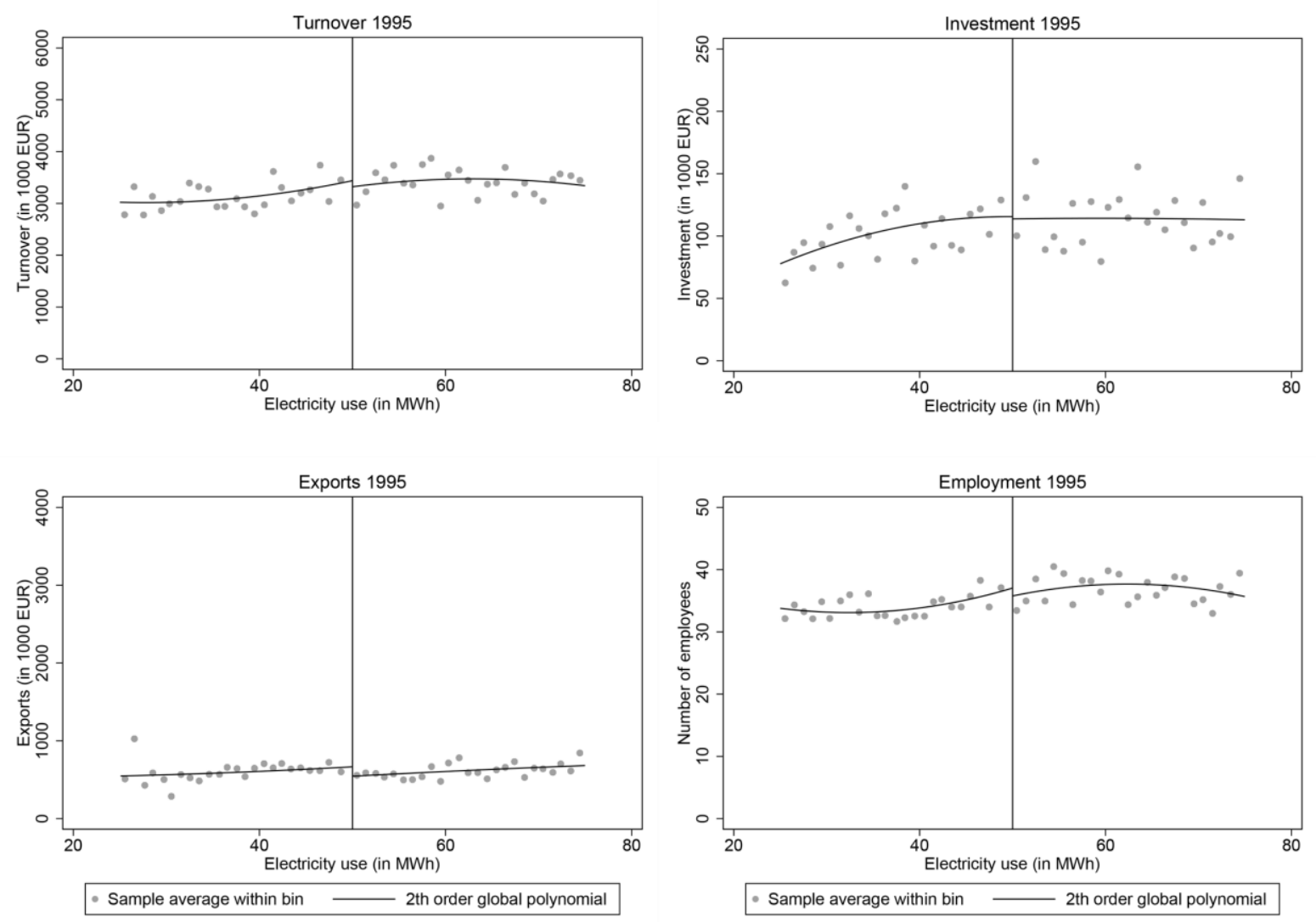

Source: Flues and Lutz (2014), ibid.

Firms within the manufacturing sector differ along many dimensions, for example, in the type of output produced, the production technologies employed and market structure faced. The effect of the reduced electricity tax rate may thus differ across manufacturing subsectors. Flues and Lutz (2015) investigate whether effects differ for the manufacturing of machinery, electronic devices and vehicles, which has higher turnover and exports than other manufacturing sectors. They do not find any systematically different effects in comparison to the analysis of the whole manufacturing sector. The manufacturing of metals, which is particularly energy-intensive, does not show any systematically different effects either.

The analysed firms fall within the lower quintile of electricity-use in the manufacturing sector. It is a question how far the results reported here apply to firms with larger electricity-use. What speaks in favour is that a wide set of firms from different sectors is analysed. This argument implicitly assumes that firms with larger electricity-use do not differ systematically from firms with lower electricity-use. What speaks against the application of the results to firms with larger electricity-use is the competing assumption that these firms are indeed different from firms with smaller electricity-use. The latter assumption implies that the results only apply to firms within the lower quintile of electricity-use in the manufacturing sector. 
Taken together, without additional information, no strong statement can be made about how far the results apply to firms with larger electricity-use than investigated. From a research perspective, the best way forward would be to look out for similar policy measures that apply to firms with very large electricity-use. From a policy perspective, the electricity-use threshold from which the reduced rate is granted could be raised, while the effects of such a change on firms' competitiveness were monitored.

\section{Conclusion}

This paper investigated the competitiveness impacts of German electricity tax that was implemented in 1999 on firms in the manufacturing sector. Firms in the manufacturing sector with electricity-use above a certain threshold were eligible for a reduced electricity tax rate. The effects of the reduced marginal electricity tax rate on turnover, investment, exports, value added and employment were evaluated with a regression discontinuity analysis. No robust positive or negative impact of the reduced marginal electricity tax rate was found. Hence, firms that had to pay the full electricity tax rate did not experience any deterioration in their competitiveness position.

The results suggest that the reduced electricity tax rate may not be needed to secure the competitiveness of firms in the manufacturing sector. Firms that had to pay the higher electricity tax did not perform worse than firms that only had to pay the reduced electricity tax rate. It can thus be expected that firms that have so far only had to pay the reduced electricity tax would also adjust smoothly if the tax reduction was removed. If there are doubts about the ability of firms with substantially higher electricityuse than investigated to adjust to the higher electricity tax rate, the electricity tax rate they pay could be increased stepwise. The threshold for eligibility of the reduced tax rate could be increased, accompanied by an evaluation of its competitiveness impacts. Removing the reduced tax rate would raise revenues that, for example, could be used to decrease distortionary taxes on labour income, consolidate budgets or finance new investment. 


\section{REFERENCES}

Adams, J. (1997), "Environmental policy and competitiveness in a globalised economy: conceptual issues and a review of the empirical evidence" in Globalisation and Environment: Preliminary Perspectives, OECD, Paris.

Arlinghaus, J. (2015), "Impacts of Carbon Prices on Indicators of Competitiveness: A Review of Empirical Findings", OECD Environment Working Papers, No.87, OECD Publishing, Paris, http://dx.doi.org/10.1787/5js37p21 grzq-en.

Braathen, N. A. (2012), "The political economy of environmental taxation" in Janet E. and Andersen, Mikael S. eds. Handbook of Research on Environmental Taxation, Edward Elgar, Cheltenham, United Kingdom, pp. 230-248.

EEX (2014), Phelix Spot, Marktdaten, EEX, Leipzig.

Flues, F. and B.J. Lutz (2015), "The effect of electricity taxation on the German manufacturing sector: A regression discontinuity approach", Discussion Paper No. 15-013, ZEW, Mannheim.

Hahn, J. Todd, J. and W. Van der Klaauw (2001), Identification and estimation of treatment effects with a regression discontinuity design”, Econometrica, Vol. 69, No. 1, pp. 201-209.

Imbens, G.W. and K. Kalyanaraman (2011), "Optimal bandwidth choice for the regression discontinuity estimator”, The Review of Economic Studies, Vol. 79, pp. 933-959.

Imbens, G.W. and T. Lemieux (2008), "Regression discontinuity designs: A guide to practice”, Journal of Econometrics, Vol. 142, No. 2, pp. 615-635.

Kozluk, T. and V. Zipperer (2013), "Environmental Policies and Productivity Growth: A Critical Review of Empirical Findings", OECD Economics Department Working Papers, No. 1096, OECD Publishing, Paris, http://dx.doi.org/10.1787/5k3w725lhgf6-en.

Lee, D.S. and T. Lemieux (2010), "Regression discontinuity designs in economics", Journal of Economic Literature, Vol. 48, No.2, pp. 281-355.

Lee, D.S. (2008), "Randomized experiments from non-random selection in the U.S. House elections", Journal of Econometrics, Vol. 48, No. 2, pp. 675-697.

Martin, R., L. de Preux and U. Wagner (2012), "The impacts of the UK climate change levy on manufacturing: Evidence from microdata", SSRN Working Paper.

Pearl, J. (2000), Causality: Models, Reasoning, and Inference. Cambridge University Press, New York.

Porter, J. (2003), “Estimation in the regression discontinuity model”, Working Paper, University of Wisconsin. 
Rivers, N. and B. Schaufele (2013), "Carbon tax, agricultural competitiveness and trade”, SSRN Working Paper.

Rubin, J. (1977), "Assignment to a treatment group on the basis of a covariate", Journal of Educational Statistics, Vol. 2, pp. 1-26.

Rubin, J. (1974), "Estimating causal effects of treatments in randomized and non-randomized studies", Journal of Educational Psychology, Vol. 66, pp. 688-701.

Smith, S. (2004), "Environmental Taxes and Competitiveness: An Overview of Issues, Policy Options, and Research Needs", OECD Papers, Volume 3, Issue 12, OECD Publishing, Paris, http://dx.doi.org/10.1787/oecd_papers-v3-12-en. 
ENV/WKP(2015)9

\section{ANNEX 1 - IDENTIFICATION OF CAUSAL EFFECTS}

The goal of the present analysis is to identify the effect of the electricity tax on firm's competitiveness. As an ad-quantum excise duty, the electricity tax increases the price per unit of electricity used by the marginal tax rate $t$. By increasing the costs associated with the use of electricity, the tax enters the production and investment decisions of a profit-maximising firm.

The identification strategy builds on variations in the marginal tax rate. Firms that are more energyintensive in terms of individual electricity-use face a lower marginal tax rate in comparison to less energy intensive firms. The reduced tax rate applies, if the electricity-use $X_{i}$ of firm $i$ exceeds the known threshold $c$ that is set by the legislative:

$$
t_{i}= \begin{cases}t_{i}(0), & \text { if } X_{i} \leq c \\ t_{i}(1), & \text { if } X_{i}>c\end{cases}
$$

where $t_{i}(0)$ denotes the regular marginal tax rate and $t_{i}(1)$ the reduced marginal tax rate, respectively. Hence, the tax reduction creates discontinuities in the marginal tax rate as a function of the individual electricity-use. This unique feature of the electricity tax allows estimating its effect on competitiveness by employing a regression discontinuity design.

The approach can be formalised within the potential outcomes framework introduced by Rubin (1974, 1977). Firms in the German manufacturing industry could have been assigned to two different groups, one of them receiving treatment (i.e., benefitting from a reduced tax rate), the other not. The binary variable $D_{i} \in\{0,1\}$ describes the treatment status of firm $i$. Let $D_{i}=1$ if the firm's electricity-use exceeds the threshold $X_{i}(0)>c$. Then the firm is subject to the reduced marginal tax rate $t_{i}(1)$ and is considered as treated. Let $D_{i}=0$ if the firm's electricity-use is lower than the threshold $X_{i}(0) \leq c$. In this case, the full marginal tax rate $t_{i}(0)$ applies and the firm is assigned to the control group. Consequently, denote the potential outcomes by

$$
Y_{i}= \begin{cases}Y_{i}(0), & \text { if } X_{i} \leq c \\ Y_{i}(1), & \text { if } X_{i}>c .\end{cases}
$$

As shown in Equation 1, the assignment to the treatment group is a deterministic function of the electricityuse $X_{i}$. Since electricity-use $X_{i}$ is observed, it can be identified if firm $i$ belongs to the treatment or the control group. Following the regression discontinuity design framework outlined by Imbens and Lemieux (2008) and Lee and Lemieux (2010), the difference in the conditional expectations to the right and the left of the threshold unveils the average causal effect of the treatment:

$$
\lim _{x \downarrow c} E\left[Y_{i} \mid X_{i}=x\right]-\lim _{x \uparrow c} E\left[Y_{i} \mid X_{i}=x\right] .
$$

In the literature, this term is interpreted as the local average treatment effect at the threshold (Imbens and Lemieux, 2008):

$$
\tau=E\left[Y_{i}(1)-Y_{i}(0) \mid X_{i}=c\right] .
$$


Making use of assumptions described in the following subsections, the treatment variation close to the threshold $c$ is considered to be random. The random assignment implies that the discontinuity at the threshold $c$ identifies the treatment effect of interest. Consequently, the effect of the electricity tax reduction can be identified by comparing firms of the treatment and controls group that are in the neighbourhood of the threshold.

As described in Section 2, the tax reduction scheme is implemented through reimbursement, i.e. firms whose electricity-use exceeds the threshold may request reimbursement from the local tax and custom agency. It is not observed, if the firms that were assigned to the treatment group received the treatment. The reimbursement procedure therefore creates imperfect compliance and frames the experiment indirect. Yet inference is possible. This case of encouraged treatment is accounted for by performing an intent-totreat analysis. Control and treatment group are compared without regards to whether the tax reduction was actually claimed. Accordingly, the average treatment effect measures how the treatment assignment affected the firm's activities, as opposed to the desired measure of how the treatment itself affected the firm's activities (Pearl, 2000).

\section{Assumptions for identifying causal effects}

\section{Inability to precisely control the assignment variable}

The central assumption underlying the identification strategy is that firms cannot precisely manipulate their individual electricity-use. Lee (2008) shows that the treatment in the regression discontinuity design is random, if the assignment variable has a continuously distributed stochastic component. This central assumption is likely to hold in the present analysis for at least two reasons. First, complex production processes in the manufacturing industry make precise manipulation of a firm's electricity-use difficult. Second, exogenous factors lead to random variation in electricity-use. For example, market conditions impact a firm's production decisions and thereby its energy use. The empirical validity of the assumption that firms cannot precisely manipulate their electricity-use was examined in Section 5 above.

\section{Probability of treatment is a discontinuous function of the assignment variable}

As shown in Equation 1, the assignment to the treatment group is a deterministic function of the variable $X_{i}$. The probability to be treated $P\left[D_{i}=1 \mid X_{i}=x\right]$ is 0 for $x \leq c$ and 1 for $x>c$.

\section{Local continuity restriction}

In absence of treatment, the outcome variable evolves continuously in the neighbourhood of the threshold. Otherwise the estimation of the local treatment effect might be biased. Lee and Lemieux (2010) suggest examining if there are discontinuities in variables that are determined prior to the assignment, in order to rule out this potential source of distortion. In Section 5, the evolution of the outcome variables was investigated as a function of the assignment variable for the years before the implementation of the electricity tax.

\section{Stable unit treatment value assumption}

The stable unit treatment value assumption (SUTVA) states that potential outcomes at one firm are independent of the treatment status of other firms. SUTVA excludes spillovers and general equilibrium effects across firms. This assumption cannot be tested. 


\section{Estimation}

The estimation of the local average treatment effect $\tau$ requires an estimator that shows good small sample properties and is suitable for inference at the boundary of the support of the regression function (here threshold $c$ ). Addressing these obstacles, Hahn et al. (2001) and Porter (2003) propose a non-parametric approach based on weighted local linear and polynomial regressions at both sides of the threshold. This estimator has become the standard choice for the estimation of local average treatment effects in the regression discontinuity literature. Yet, the estimator requires the selection of a bandwidth that determines the range around the threshold that is exploited for the estimation of the local regressions. A fully datadriven bandwidth algorithm developed by Imbens and Kalyanaraman (2012) is used to select the optimal bandwidth.

The estimator for the local average treatment effect at the threshold $\hat{\tau}$ developed by Imbens and Kalyanaraman (2012) is given by

$$
\hat{\tau}=\widehat{\alpha}_{+, p}-\widehat{\alpha}_{-, p}
$$

where $\widehat{\alpha}_{+, p}$ and $\widehat{\alpha}_{-, p}$ denote the constants of a weighted polynomial regression. The weights are computed by applying a kernel function on the distance of each observation's score to the threshold $c$. The parameters are obtained by estimating two equations within two narrow windows left and right of the threshold that yield in the estimator $\widehat{\alpha}_{+}$for only treated and the estimator $\widehat{\alpha}_{-}$for only control firms:

$$
\begin{aligned}
& \left(\widehat{\alpha}_{+}, \widehat{\beta}_{+}\right)=\operatorname{argmin}_{\alpha, \beta} \sum_{i=1}^{N} \mathbf{1}_{X_{i>c}}\left(Y_{i}-\alpha-\beta\left(X_{i}-c\right)\right) K\left(\frac{X_{i}-c}{h}\right) \\
& \left(\widehat{\alpha}_{-}, \widehat{\beta}_{-}\right)=\operatorname{argmin}_{\alpha, \beta} \sum_{i=1}^{N} \mathbf{1}_{X_{i>c}}\left(Y_{i}-\alpha-\beta\left(X_{i}-c\right)\right) K\left(\frac{X_{i}-c}{h}\right)
\end{aligned}
$$

where $\mathbf{1}_{u}$ is an indicator function taking the value 1 if condition $u$ is fulfilled. In order to select the optimal bandwidth $h$ for the two windows, the algorithm developed by Imbens and Kalyanaraman (2012) is employed. The default kernel function $K$ is triangular. The computed standard errors are robust with respect to heteroskedasticity and show good finite sample properties. 